AGRICULTURE AND BIOLOGY JOURNAL OF NORTH AMERICA

ISSN Print: 2151-7517, ISSN Online: 2151-7525, doi:10.5251/abjna.2010.1.6.1309.1318

(C) 2010, ScienceHuß, http://www.scihub.org/ABJNA

\title{
Influence of some post-harvest treatments on guava fruits
}

\author{
Omayma M. Ismail $^{1}$, Eman, A.A. Abd El-Moniem ${ }^{1}$; A.S.E. Abd- Allah ${ }^{1}$ and M.A.A. El- \\ Naggar \\ ${ }^{1}$ Horticultural Crops Technology Dept., NRC, Dokki, Giza, Egypt \\ ${ }^{2}$ Plant Pathology Dept., NRC, Dokki, Giza, Egypt
}

\begin{abstract}
Guava (Psidium juajava L.) is highly perishable, susceptible to mechanical damage and chilling injury and has a limited postharvest shelf life. This study explored the use of some postharvest treatments to extend the marketable shelf life of guava and to alleviate some pathogenic disorders. Mature yellowish-green guava fruits $\mathrm{cv}$. were treated with hot water, hydrogen peroxide $\left(\mathrm{H}_{2} \mathrm{O}_{2}\right)$, calcium chloride grass oil fumigation and various combination between them and then stored at $8 \pm 1^{\circ} \mathrm{C}$ with $90 \%$ relative humidity $(\mathrm{RH})$ for 15 days. Fruits were transferred to room conditions at $\left(22 \pm 2^{\circ} \mathrm{C}\right.$ and $\left.55-60 \% \mathrm{RH}\right)$ till the end of the fruit marketable period. Fruits of all treatments showed lower fruit weight loss, decayed fruits and long marketable-life period in comparison to untreated (water only). Calcium chloride + lemon grass fumigation treatment gave fruits with high quality than other treated fruits. Ascorbic acid and total pectin values were the highest with calcium chloride + lemon grass fumigation treatment than in the control and other treated fruits, whereas acid \% and SSC values were the lowest. All tested treatments greatly reduced rhizopus rot infection value after 10 days at $8 \pm 1^{\circ} \mathrm{C}$, rot infection percent was $100 \%$ in control fruit, whereas very little infection value was observed in treated fruit. Fruits treated with Calcium chloride + lemon grass fumigation were completely rhizopus rot free through 15 days storage at $8 \pm 1^{\circ} \mathrm{C}$. The sensory evaluation showed that this treatment could maintain appearance considered the most benefit fruit appearance ,physical, chemical fruit properties and free from rots at $8 \pm 1^{\circ} \mathrm{C}$ for two weeks. This treatment considered the most benefit tested one.
\end{abstract}

Keywords: Guava, Post-harvest treatments, Hot water, Hydrogen peroxide Calcium chloride, Lemon grass oil fumigation, Physical and Chemical properties, Marketable, Shelf life.

\section{INTRODUCTION}

Guava (Psidium guajava L.) is an important resource in the domestic economy of many countries in the tropics (Yavada 1996). Guava is a very popular fruit; it is generally a good source of lycopene, betacarotene, vitamin $\mathrm{C}$, protein, fat, carbohydrate, fibers, minerals, vitamin B \& B2 and is an excellent source of (Whole Health MD, 2000).

In Egypt, Guava trees are widely planted especially in Beheira, El-Sharkia, around Alexandria and newly reclaimed lands. Guava can grow in many types of soil and it can grow under a wide range of climatic and soil conditions and can tolerate alkaline soil up to $\mathrm{pH} 8.2$ (Samson, 1980).

In Egypt guava occupy about 38000 feddan, yielded about 314000 ton as annual fruit production with an exported range about 16.312 .38 metric tons to many countries. Guava exports from Egypt are increased through air flight as the main transport system. The limiting factor for export is the high costs that reduce the profit level to the grower. Refrigeration appears to be a suitable way for sea transport. The guava is highly perishable, susceptible to mechanical damage and chilling injury and has a limited postharvest shelf life.

Soft rot of guava caused by Rhizopus stolonifer (Ehrenb) resulted in problems during storage and exported process (Adisa, 1985).

Post-harvest treatments with hot water have been well studied for controlling post-harvest decay of citrus fruits (Lurie, 1999), also in the case of longterm refrigerated storage for improving fruit resistance to chilling injury (Rodov et al 1995).

Juven and Pierson (1996) reviewed research reports on the antimicrobial activity of $\mathrm{H}_{2} \mathrm{O}_{2}$ and its use in the food industry.

Post-harvest applications with calcium chloride have been used to delay aging or ripening, consequently reducing post-harvest decay and controlling many 
diseases in fruits and vegetables (Cheaour et al., 1990 and 1991 and El-Gamal et al., 2007).

Essential oil extracted from lemon grass (Cymbopogon citreatus DC.) has antifungal activity against several plant pathogens (Raweewon, 2008).

The present investigation was designed to study the effect of some post-harvest treatments such as hot water, Hydrogen peroxide, calcium chloride and lemon grass extract for prolonging the cold storage period and shelf life of Maamoura guava fruits.

\section{MATERIALS AND METHODS}

This study was conducted during the two successive seasons 2006 and 2007 at the Agriculture Development System (ADS) project at Faculty of Agriculture, Cairo University.

Fruits from mature Maamoura trees grown in a private orchard in Rashid (Bahaira Governorate) were picked at maturity stage (yellowish green). In both experimental seasons, fruits were brought to the post harvest laboratory immediately after harvesting in plastic boxes (15 kg capacity). Detective fruits including wounded and other disorders were excluded, the rest considered as sound fruits (at the same maturity stage) which washed with tap water

Clean sound fruits were subjected to the following treatments:

1. Dipping in tap water only (control).

2. Dipping in hot water at $48^{\circ} \mathrm{C}$ for two minutes.

3. Dipping in hydrogen peroxide $\left(\mathrm{H}_{2} \mathrm{O}_{2}\right)$ at $2 \%$ for four minutes.

4. Dipping in calcium chloride $\left(\mathrm{CaCl}_{2}\right)$ at $2 \%$ for four minutes

5. Fumigation with crude lemon grass oil (6 $\mathrm{ml} /$ carton concentration) treated on wall of carton.

6. Dipping in hot water at $48^{\circ} \mathrm{C}$ for two minutes+ fumigation with crude lemon grass oil $(6 \mathrm{ml} /$ carton box)

7. Dipping in $\mathrm{H}_{2} \mathrm{O}$ at $2 \%$ for four minutes + fumigation with crude lemon grass oil (6 $\mathrm{ml} /$ carton box)

8. Dipping in $\mathrm{CaCl}_{2}$ at $2 \%$ for four minutes + fumigation with crude lemon grass oil (6 $\mathrm{ml} /$ carton box).
Each treatment was represented by three replicates each of them was packed in 3 carton boxes $3 \mathrm{~kg}$ with dimensions of $45 \times 35 \times 10 \mathrm{~cm}$. Experimental boxes were stored at $8 \pm 1^{\circ} \mathrm{C}$ and $90 \%$ relative humidity for 15 days.

A sample was examined for Physical, chemical properties and sensory evaluation at the beginning and then every three days intervals.

\section{Physical properties}

Fruit weight loss percentage: Each box was individually weighted before cold storage to get the initial weight, and then weighted after each period of cold storage. Fruits weight was recorded, then the percentage of weight loss were calculated according to the following equation:

$$
\text { Fruit weight loss } \%=\frac{\mathrm{Wi}-\mathrm{Ws}}{\mathrm{Wi}} \times 100
$$

Where:

$\mathrm{Wi}=$ fruit weight at initial period

Ws = fruit weight at sampling period

Visual appearance: Was measured by a rating system and fruit was scored as: very good $=9$, good $=7$, acceptable $=5$, unacceptable $=3$, poor $=1$

Fruit decay \%: The number of decayed fruits due to fungus or any micro-organisms infection was recorded every 3 days and calculated as a percentage of the total number of fruits using the following equation:

$$
\text { Fruit decay } \%=\frac{\text { Number of decay fruit }}{\text { Initial number of stored fruits }} \times 100
$$

Marketable (Shelf life) period (in days): After 15 days of cold storage a fruit sample from each replicates was taken out and stored at room conditions $\left(22 \pm 2^{\circ} \mathrm{C}\right.$ and $55-60 \%$ RH) till bad appearance or rotting occurs. Then, the number of days was recorded and considered as shelf life.

\section{Chemical properties}

Soluble solids content \%: Abbe refractometer was used to determine the percentage of soluble solids content in flesh fruit juice.

Titratable acidity \%: Was determined according to the method described in A.O.A.C. (1990) Results were expressed as \% of malic acid in fresh pulp weight. 
Ascorbic acid content: Was determined according to Lucass, 1944, it was calculated as milligram vitamin C per $100 \mathrm{gm}$ of fresh weight.

Total sugars \%: Was determined by using the methods of Smith et al. (1956) and the concentration was calculated as gm glucose per $100 \mathrm{gm}$. fresh weight.

Determination of antifungal activity of lemon grass oil: Lemon grass oil was extracted by steam distillation of wilted leaves of lemon grass (Cymbopogon citratus (staph.) according to the procedure of Sheffer et al. (1977).

Directly added to the medium: To determine the interaction of the medium with oil components, it was directly added to PDA medium. The crude oil concentration ranged from 20 to $100 \mathrm{ppm}$. The oil was solubilized in the PDA medium using $0.03 \%$ Tween 80 . Ten $\mathrm{ml}$ of the mixture from liquid media and oil were poured into Petri-dishes, and then the agar discs bearing on the fungus were placed in the center. The dishes were incubated at $28^{\circ} \mathrm{C}$. On the seventh day, the growth of the fungi was recorded.

Indirectly applied as vapor: The presence of volatile inhibitory compounds was tested using small dishes $(90 \times 15 \mathrm{~mm})$, containing PDA without cover and inoculated with the fungi tested then placed inside a large Petri-dish $(140 \times 23 \mathrm{~mm})$ together, while the tested oil was placed in large Petri-dish. The control ones were not treated with oil in large Petri-dish. The large dishes were sealed and kept at $25^{\circ} \mathrm{C}$. The linear growth of fungi was measured daily for 10 days.

Effect of different treatments on linear growth of rot fungi: Hydrogen peroxide (2\%), calcium chloride $(2 \%)$ and lemon grass $(6 \mathrm{ml})$ concentrations were tested to study their inhibitory effect on linear growth of $R$. stolonifer as causal agents of soft rot disease. Tested treatments were added to conical flasks containing sterilized PDA medium to obtain in proposed concentration, then rotated gently and dispensed in sterilized Petri plates (10 cm diameter). Plates were individually inoculated at the center with equal disks (5 mm diameter) of 7 days old culture of $R$. stolonifer. Five plates were used as replicates for each particular treatment. Inoculated plates were incubated at $25^{\circ} \mathrm{C}$. The average linear growth of fungi tested was calculated after 10 days.

Inhibition of decay in harvested guava fruits by lemon grass oil vapor: About $24 \mathrm{~h}$ after guava harvest, fruits were packed in carton boxes and treated with 2, 4, or $6 \mathrm{ml}$ of lemon grass oil/carton box, while control was treated with water only. The results were obtained using of infection $\%$ according to (Chastanger and Ogawa, 1979).

\section{Effect of different treatments on post-harvest rots of guava}

Inoculation of fruits: Inoculation of guava fruits was carried out by spraying fruits with spore suspension $\left(10^{6} \mathrm{spores} / \mathrm{ml}\right)$ of $R$. stolonifer as causal agents of soft rot disease, then air dried at room temperature at $23-25^{\circ} \mathrm{C}$. All treated of each particular concentration as well as control treatment were represented at four replicates with 20 fruits for each replicate. All fruits were stored at $20 \pm 2^{\circ} \mathrm{C}$ for 15 days and the percentage of infection was recorded.

Statistical analysis: All the obtained data were tabulated and the analysis of variance was determined according to the procedure of (Snedecor and Cochran).

\section{RESULTS AND DISCUSSION}

Effect of some post-harvest treatments on physical and chemical properties of guava fruits Effect on physical properties

Weight loss \%: Data in Table (1) indicate that a gradual increase in weight loss was shown towards the end of storage period. Fruits treated with $\mathrm{CaCl}_{2}$ + fumigation with lemon grass oil and stored at $8 \pm 1^{\circ} \mathrm{C}$ recorded the lowest significant value of weight loss (5.00\%) in the first season and $5.25 \%$ in the second one.

On the other hand, hot water treatment exhibited the highest weight loss value $(8.04,8.22)$ in both seasons, respectively. In this regard, Ahmed Amen (1987) and Singh et al. (1981) stated that dipping guava fruits in calcium chloride (0.5-2.0\%) reduced weight loss and respiration rate. These data can be explained by the fact that $\mathrm{CaCl}_{2}$ is hydroscopic (absorbs moisture), which is believed to be one of the reasons for its effectiveness in controlling weight loss. Water vapour absorbed from the storage room helps to provide a continuous solution of $\mathrm{CaCl}_{2}$ on the surface of the fruit throughout storage period. These observations are very close to those obtained by Kartar \& Chauhan (1983); et al. (1984) and Shaaban, Fatma (2006).

Visual appearance: Results in Table (2) indicated that at the end of storage period (15 days), fruits 
treated with $2 \% \mathrm{CaCl}_{2}+$ fumigation with lemon grass oil $(6 \mathrm{ml})$ and stored at $8 \pm 1^{\circ} \mathrm{C}$ exhibited the higher fruit appearance score (7.94 and 7.75) at the two seasons, respectively, whereas the control fruits showed the lowest score (5.0 and 6.0)
In this regard and Reddy (1990); Crisosto and Michailides (1991); Pathmanaban et al (1995) and Sabry (1998) noted that dipping guava fruits in hot water at $50^{\circ} \mathrm{C}$ or $\mathrm{CaCl}_{2}$ decreased fruit rot and preserved storage quality also treated fruits received significantly higher quality ratings than untreated control.

Table 1. Effect of some post-harvest treatments on weight loss \% of Maamoura guava fruits stored at $8 \pm 1^{\circ} \mathrm{C}$ and 90\% RH during 2006 and 2007 seasons

\begin{tabular}{|c|c|c|c|c|c|c|c|c|c|c|}
\hline \multirow{3}{*}{ Treatments } & \multicolumn{5}{|c|}{ Season 2006} & \multicolumn{5}{|c|}{ Season 2007} \\
\hline & \multicolumn{10}{|c|}{ Storage periods/days } \\
\hline & 3 & 6 & 9 & 12 & 15 & 3 & 6 & 9 & 12 & 15 \\
\hline Control (water only) & 2.08 & 3.62 & 4.75 & 7.24 & 9.40 & 2.65 & 3.95 & 4.80 & 7.11 & 9.35 \\
\hline Hot water at $\left(48^{\circ} \mathrm{C}\right)$ for 2 minutes & 2.40 & 3.85 & 4.12 & 7.20 & 8.04 & 2.72 & 4.00 & 5.14 & 7.30 & 8.22 \\
\hline Hydrogen peroxide (2\%) for 4 minutes & 1.52 & 2.40 & 4.02 & 5.95 & 7.60 & 1.75 & 2.97 & 4.10 & 5.76 & 7.90 \\
\hline Calcium chloride (2\%) for 4 minutes & 1.10 & 1.96 & 3.07 & 5.14 & 6.02 & 1.45 & 2.15 & 3.30 & 5.25 & 6.40 \\
\hline Lemon grass $6 \mathrm{ml} /$ carton (fumigation) & 1.70 & 2.19 & 4.15 & 6.07 & 7.04 & 1.91 & 3.03 & 4.75 & 6.15 & 7.42 \\
\hline Hot water + lemon grass (fumigation) & 1.40 & 2.20 & 4.60 & 6.00 & 6.75 & 1.86 & 3.70 & 5.00 & 6.45 & 7.10 \\
\hline $\begin{array}{l}\text { Hydrogen peroxide }+ \text { lemon } \\
\text { (fumigation) }\end{array}$ & 1.25 & 2.15 & 4.17 & 5.11 & 6.30 & 1.66 & 3.43 & 4.85 & 5.20 & 6.32 \\
\hline Calcium chloride + lemon grass (fumigation) & 1.15 & 2.20 & 3.11 & 4.35 & 5.00 & 1.60 & 2.10 & 3.40 & 4.75 & 5.25 \\
\hline LSD at $5 \%$ & 0.21 & 0.36 & 0.48 & 0.93 & 0.98 & 0.23 & 0.41 & 0.52 & 0.82 & 1.03 \\
\hline
\end{tabular}

Table 2. Effect of some post-harvest treatments on visual appearance of Maamoura guava fruits stored at $8 \pm 1^{\circ} \mathrm{C}$ and 90\% RH during 2006 and 2007 seasons

\begin{tabular}{|c|c|c|c|c|c|c|c|c|c|c|}
\hline \multirow{3}{*}{ Treatments } & \multicolumn{5}{|c|}{ Season 2006} & \multicolumn{5}{|c|}{ Season 2007} \\
\hline & \multicolumn{10}{|c|}{ Storage periods/days } \\
\hline & 3 & 6 & 9 & 12 & 15 & 3 & 6 & 9 & 12 & 15 \\
\hline Control (water only) & 9.00 & 9.00 & 7.00 & 5.67 & 5.00 & 9.00 & 9.00 & 9.00 & 7.40 & 6.00 \\
\hline at $\left(48^{\circ} \mathrm{C}\right)$ for 2 minutes $)$ & 9.00 & 9.00 & 9.00 & 7.70 & 6.92 & 9.00 & 9.00 & 9.00 & 8.00 & 6.33 \\
\hline Hydrogen peroxide (2\%) & 9.00 & 9.00 & 9.00 & 8.20 & 7.30 & 9.00 & 9.00 & 9.00 & 7.20 & 6.70 \\
\hline Calcium chloride (2\%) for 4 minutes & 9.00 & 9.00 & 9.00 & 8.45 & 7.45 & 9.00 & 9.00 & 9.00 & 8.00 & 7.33 \\
\hline Lemon gra & 9.00 & 9.00 & 9.00 & 8.60 & 7.15 & 9.00 & 9.00 & 9.00 & 6.95 & 6.20 \\
\hline Hot water + lemon grass (fumigation) & 9.00 & 9.00 & 9.00 & 8.70 & 7.63 & 9.00 & 9.00 & 9.00 & 8.33 & 7.25 \\
\hline $\begin{array}{l}\text { Hydrogen peroxide } \\
\text { (fumigation) }\end{array}$ & 9.00 & 9.00 & 9.00 & 8.75 & 7.80 & 9.00 & 9.00 & 9.00 & 8.33 & 7.30 \\
\hline Calcium chloride + lemon grass (fumigation) & 9.00 & 9.00 & 9.00 & 9.00 & 7.94 & 9.00 & 9.00 & 9.00 & 8.80 & 7.75 \\
\hline LSD at $5 \%$ & 0.0 & 0.0 & 0.0 & 0.60 & 0.81 & 0.0 & 0.0 & 0.0 & 0.72 & 0.8 \\
\hline
\end{tabular}

Fruit decay percentage: Data in Table (3) showed that all treatments gave a longer storage life than the control, since instance decayed fruits were about 7 and $8 \%$ for the control fruits after 15 days in the two seasons, respectively. No decayed fruits were observed among our treatments at the end of storage period (15 days). This wide variation in fruit decay $\%$ of heated fruits than the control may have obscured the effect of the tested treatments.

In this regard, and Reddy (1990); Majumdar and Pathak (1991) noted that severity of rots significantly decreased when the fruits were treated with hot water at $50^{\circ} \mathrm{C}$. On the other hand, Crisosto and Michailides (1991) and Sabry (1998) pointed out that post harvest calcium application decreased decay incidence.
Marketable (Shelf life) period: Data tabulated in Table (4) showed that the longest marketable period was obtained with fruits treated by $\mathrm{CaCl}_{2}+$ lemon grass oil vapors or fruits treated by $\mathrm{H}_{2} \mathrm{O}_{2}+$ lemon grass oil vapors(6.30 days),(6.45 days) and (6.20 days), (6.37 days) was recorded in the first and second seasons, respectively. Whereas, the shortest life was noticed with control (4.15 and 4.27 day) in the two seasons, respectively followed by $\mathrm{H}_{2} \mathrm{O}_{2}$ treatment (5.00 days) in the first season while it was 5.40 days with hot water treatment in the second season.

In this respect, Pathmanaban et al. (1995) reported that the $\mathrm{CaCl}_{2}$ dip treatment prolonged shelf life. 


\section{AGRICULTURE AND BIOLOGY JOURNAL OF NORTH AMERICA}

ISSN Print: 2151-7517, ISSN Online: 2151-7525, doi:10.5251/abjna.2010.1.6.1309.1318

(C) 2010, ScienceHuß, http://www.scihub.org/ABJNA

Table 3. Effect of some post-harvest treatments on fruit decay $\%$ of Maamoura guava fruits stored at $8 \pm 1{ }^{\circ} \mathrm{C}$ and $90 \%$ RH during 2006 and 2007 seasons

\begin{tabular}{|c|c|c|c|c|c|c|c|c|c|c|}
\hline \multirow{3}{*}{ Treatments } & \multicolumn{5}{|c|}{ Season 2006} & \multicolumn{5}{|c|}{ Season 2007} \\
\hline & \multicolumn{10}{|c|}{ Storage periods/days } \\
\hline & 3 & 6 & 9 & 12 & 15 & 3 & 6 & 9 & 12 & 15 \\
\hline Control (water only) & 0.00 & 0.00 & 0.00 & 1.27 & 7.10 & 0.00 & 0.00 & 0.00 & 2.20 & 8.30 \\
\hline Hot water at $\left(48^{\circ} \mathrm{C}\right)$ for 2 minutes & 0.00 & 0.00 & 0.00 & 0.00 & 0.00 & 0.00 & 0.00 & 0.00 & 0.00 & 0.00 \\
\hline Hydrogen peroxide $(2 \%)$ for 4 minutes & 0.00 & 0.00 & 0.00 & 0.00 & 0.00 & 0.00 & 0.00 & 0.00 & 0.00 & 0.00 \\
\hline Calcium chloride (2\%) for 4 minutes & 0.00 & 0.00 & 0.00 & 0.00 & 0.00 & 0.00 & 0.00 & 0.00 & 0.00 & 0.00 \\
\hline Lemc & 0.00 & 0.00 & 0.00 & 0.00 & 0.00 & 0.00 & 0.00 & 0.00 & 0.00 & 0.00 \\
\hline Hot water + lemon grass (fumigation) & 0.00 & 0.00 & 0.00 & 0.00 & 0.00 & 0.00 & 0.00 & 0.00 & 0.00 & 0.00 \\
\hline $\begin{array}{l}\text { Hydrogen } \\
\text { (fumigation) }\end{array}$ & 0.00 & 0.00 & 0.00 & 0.00 & 0.00 & 0.00 & 0.00 & 0.00 & 0.00 & 0.00 \\
\hline Calcium chloride + lemon g & 0.00 & 0.00 & 0.00 & 0.00 & 0.00 & 0.00 & 0.00 & 0.00 & 0.00 & 0.00 \\
\hline LSD at $5 \%$ & 0.00 & 0.00 & 0.00 & 0.00 & 0.00 & 0.00 & 0.00 & 0.00 & 0.00 & 0.00 \\
\hline
\end{tabular}

Table 4. Effect of some post-harvest treatments on marketable period in days of Maamoura guava fruits stored at $8 \pm 1^{\circ} \mathrm{C}$ and $90 \% \mathrm{RH}$ during 2006 and 2007 seasons.

\begin{tabular}{|l|c|c|}
\hline \multicolumn{1}{|c|}{ Treatments } & $\begin{array}{l}\text { Season } \\
2006\end{array}$ & $\begin{array}{l}\text { Season } \\
2007\end{array}$ \\
\hline Control (water only) & 4.15 & 4.27 \\
\hline Hot water at (48 ${ }^{\circ}$ ) for 2 minutes & 5.28 & 5.40 \\
\hline $\begin{array}{l}\text { Hydrogen peroxide (2\%) for 4 } \\
\text { minutes }\end{array}$ & 5.00 & 5.47 \\
\hline $\begin{array}{l}\text { Calcium chloride (2\%) for 4 } \\
\text { minutes }\end{array}$ & 5.50 & 5.90 \\
\hline $\begin{array}{l}\text { Lemon grass 6 ml/ carton } \\
\text { (fumigation) }\end{array}$ & 5.90 & 6.00 \\
\hline $\begin{array}{l}\text { Hot water + lemon grass } \\
\text { (fumigation) }\end{array}$ & 6.00 & 6.30 \\
\hline $\begin{array}{l}\text { Hydrogen peroxide)+ lemon grass } \\
\text { (fumigation) }\end{array}$ & 6.20 & 6.37 \\
\hline $\begin{array}{l}\text { Calcium chloride + lemon grass } \\
\text { (fumigation) }\end{array}$ & 6.30 & 6.45 \\
\hline LSD at 5\% & 0.63 & 0.42 \\
\hline
\end{tabular}

Table 5. Effect of some post-harvest treatments on soluble solids content (\%) of Maamoura guava fruits stored at $8 \pm 1^{\circ} \mathrm{C}$ and $90 \% \mathrm{RH}$ during 2006 and 2007 seasons

\begin{tabular}{|c|c|c|c|c|c|c|c|c|c|c|c|c|}
\hline \multirow{3}{*}{ Treatments } & \multicolumn{6}{|c|}{ Season 2006} & \multicolumn{6}{|c|}{ Season 2007} \\
\hline & \multicolumn{12}{|c|}{ Storage periods/days } \\
\hline & 0 & 3 & 6 & 9 & 12 & 15 & 0 & 3 & 6 & 9 & 12 & 15 \\
\hline Control (water only) & 7.4 & 7.8 & 8.7 & 9.2 & 10.1 & 10.9 & 8.0 & 8.3 & 8.8 & 9.2 & 10.5 & 11.2 \\
\hline Hot water at $\left(48^{\circ} \mathrm{C}\right)$ for 2 minutes & 7.4 & 7.6 & 8.4 & 9.0 & 9.7 & 10.5 & 8.0 & 8.2 & 8.7 & 9.2 & 10.1 & 10.9 \\
\hline Hydrogen peroxide (2\%) for 4 minutes & 7.4 & 7.7 & 8.4 & 9.1 & 9.7 & 10.4 & 8.0 & 8.2 & 8.6 & 9.0 & 10.0 & 10.7 \\
\hline Calcium chloride (2\%) for 4 minutes & 7.4 & 7.6 & 8.1 & 8.9 & 9.4 & 10.2 & 8.0 & 8.1 & 8.4 & 8.7 & 9.5 & 10.4 \\
\hline Lemon grass $6 \mathrm{ml} /$ carton (fumigation) & 7.4 & 7.8 & 8.5 & 9.2 & 9.6 & 10.0 & 8.0 & 8.4 & 8.7 & 9.0 & 9.3 & 9.9 \\
\hline Hot water + lemon grass (fumigation) & 7.4 & 7.9 & 8.1 & 9.0 & 9.6 & 9.9 & 8.0 & 8.2 & 8.4 & 8.7 & 9.5 & 10.0 \\
\hline $\begin{array}{l}\text { Hydrogen peroxide }+ \text { lemon grass } \\
\text { (fumigation) }\end{array}$ & 7.4 & 7.7 & 8.2 & 8.8 & 9.5 & 9.9 & 8.0 & 8.1 & 8.5 & 8.8 & 9.3 & 9.8 \\
\hline $\begin{array}{l}\text { Calcium chloride }+ \text { lemon grass } \\
\text { (fumigation) }\end{array}$ & 7.4 & 7.6 & 8.3 & 8.7 & 9.2 & 9.6 & 8.0 & 8.2 & 8.5 & 8.6 & 9.1 & 9.5 \\
\hline LSD at $5 \%$ & 0.0 & 0.03 & 0.2 & 0.1 & 0.5 & 0.3 & 0.0 & 0.01 & 0.6 & 0.5 & 0.2 & 0.3 \\
\hline
\end{tabular}

\section{Effect on chemical properties}

Soluble solids content (SSC \%): It is clear from table (5) that SSC\% increased gradually till the end of storage. While the increase in flesh SSC was gradual for treated fruits, it was high with the controls. This is probably due to the difference in moisture loss from fruits of different tested treatments.

The obtained results were similar to those mentioned by Nawar and Ezz (1994); Ahmed (1995); Sabry (1998) and Aly and Ismail (2000) who noted that guava fruits treated with $\mathrm{CaCl}_{2}$ had lower SSC $\%$ compared to the control. Also, $\mathrm{CaCl}_{2}$ reduced skin browning and polyphenol oxidase activity compared with control. High incidence of fruit browning was generally associated with low SSC contents. 


\section{AGRICULTURE AND BIOLOGY JOURNAL OF NORTH AMERICA}

ISSN Print: 2151-7517, ISSN Online: 2151-7525, doi:10.5251/abjna.2010.1.6.1309.1318

(C) 2010, ScienceHuß, http://www.scihub.org/ABJNA

Flesh acid \%: Data presented in Table (6) indicated that there was noticeable increase in the flesh acidity during the first three sampling dates followed by a sizable decrease till the end of the storage period (15days). This sizable decrease could be attributed to its use as a substrate for respiration. Control fruits showed the higher flesh acid content value in the two seasons, also it could be noticed that there was no definite trend between treatments in this respect in the two seasons.

Table 6. Effect of some post-harvest treatments on total acidity $\%$ in flesh of Maamoura guava fruits stored at $8 \pm 1^{\circ} \mathrm{C}$ and $90 \%$ RH during 2006 and 2007 seasons

\begin{tabular}{|c|c|c|c|c|c|c|c|c|c|c|c|c|}
\hline \multirow{3}{*}{ Treatments } & \multicolumn{6}{|c|}{ Season 2006} & \multicolumn{6}{|c|}{ Season 2007} \\
\hline & \multicolumn{12}{|c|}{ Storage periods/day } \\
\hline & 0 & 3 & 6 & 9 & 12 & 15 & 0 & 3 & 6 & 9 & 12 & 15 \\
\hline $\begin{array}{l}\text { Control } \\
\text { (water only) }\end{array}$ & 0.172 & 0.184 & 0.200 & 0.224 & 0.206 & 0.193 & 0.170 & 0.195 & 0.217 & 0.249 & 0.203 & 0.198 \\
\hline $\begin{array}{l}\text { Hot water at } \\
\left(48^{\circ} \mathrm{C}\right) \text { for } 2 \\
\text { minutes }\end{array}$ & 0.172 & 0.175 & 0.1858 & 0.202 & 0.197 & 0.184 & 0.170 & 0.190 & 0.203 & 0.221 & 0.189 & 0.185 \\
\hline $\begin{array}{l}\text { Hydrogen } \\
\text { peroxide } \\
(2 \%) \text { for } 4 \\
\text { minutes }\end{array}$ & 0.172 & 0.179 & 0.190 & 0.197 & 0.162 & 0.180 & 0.170 & 0.186 & 0.200 & 0.215 & 0.201 & 0.180 \\
\hline $\begin{array}{l}\text { Calcium } \\
\text { chloride } \\
(2 \%) \text { for } 4 \\
\text { minutes }\end{array}$ & 0.172 & 0.182 & 0.211 & 0.265 & 0.207 & 0.170 & 0.170 & 0.187 & 0.194 & 0.213 & 0.200 & 0.175 \\
\hline $\begin{array}{l}\text { Lemon grass } \\
6 \text { ml/ carton } \\
\text { (fumigation) }\end{array}$ & 0.172 & 0.172 & 0.184 & 0.195 & 0.173 & 0.168 & 0.170 & 0.190 & 0.201 & 0.210 & 0.200 & 0.175 \\
\hline $\begin{array}{l}\text { Hot water + } \\
\text { lemon grass } \\
\text { (fumigation) }\end{array}$ & 0.172 & 0.180 & 0.192 & 0.225 & 0.208 & 0.175 & 0.170 & 0.192 & 0.221 & 0.222 & 0.210 & 0.172 \\
\hline $\begin{array}{l}\text { Hydrogen } \\
\text { peroxide + } \\
\text { lemon grass } \\
\text { (fumigation) }\end{array}$ & 0.172 & 0.177 & 0.190 & 0.210 & 0.203 & 0.166 & 0.170 & 0.185 & 0.201 & 0.213 & 0.198 & 0.168 \\
\hline $\begin{array}{l}\text { Calcium } \\
\text { chloride + } \\
\text { lemon grass } \\
\text { (fumigation) }\end{array}$ & 0.172 & 0.175 & 0.180 & 0.200 & 0.188 & 0.160 & 0.170 & 0.182 & 0.200 & 0.214 & 0.191 & 0.165 \\
\hline LSD at $5 \%$ & 0.0 & 0.20 & 0.11 & 0.10 & 0.16 & 0.12 & 0.0 & 0.30 & 0.13 & 0.15 & 0.19 & 0.10 \\
\hline
\end{tabular}

Ascorbic acid content: Data in Table (7) showed that ascorbic acid content seemed to be decreased in storage. Tested treatments seemed to have no definite trend in this respect; it showed that ascorbic acid content in fruits decreased gradually with advanced storage. These results were agreed with those obtained by Roberto et al. (1990); Siddiqui et al. (1991) and Salmah-Yusof et al. (1992). On the other hand, Nawar and Ezz (1994) who reported that guava fruits treated with $\mathrm{CaCl}_{2}$ had higher ascorbic acid content compared with the control. The same results were reported by Aly and Ismail (2000) and Shaaban, Fatma (2006).

Total sugars \%: Data in Table (8) demonstrated that total sugars $\%$ increased gradually with the advance in cold storage periods up to 15 days. The highest total sugars \% was obtained by $\mathrm{CaCl}_{2}+$ lemon grass vapors treatment $(8.89 \%),(9.50 \%)$ in the first and second seasons, respectively. The least value in the first season was recorded by fruits treated with hot water (7.40\%), while $\mathrm{CaCl}_{2}$ treated fruits recorded the least value $(7.50 \%)$ in the second season.

In this regard, Nickhah et al. (1999) found that treating pear fruits with $\mathrm{CaCl}_{2}$ solutions reduced sugar contents. On the other hand, Shaaban, Fatma (2006) found that the lowest sugar values were obtained from guava fruits treated by hot water and by $\mathrm{CaCl}_{2}$ treated fruits. 


\section{AGRICULTURE AND BIOLOGY JOURNAL OF NORTH AMERICA}

ISSN Print: 2151-7517, ISSN Online: 2151-7525, doi:10.5251/abjna.2010.1.6.1309.1318

(C) 2010, ScienceHuß, http://www.scihub.org/ABJNA

Table 7. Effect of some post-harvest treatments on ascorbic acid content (mg/100 gm flesh) of Maamoura guava fruits stored at $8 \pm 1^{\circ} \mathrm{C}$ and $90 \%$ RH during 2006 and 2007 seasons

\begin{tabular}{|c|c|c|c|c|c|c|c|c|c|c|c|c|}
\hline \multirow{3}{*}{ Treatments } & \multicolumn{6}{|c|}{ Season 2006} & \multicolumn{6}{|c|}{ Season 2007} \\
\hline & \multicolumn{12}{|c|}{ Storage periods/day } \\
\hline & 0 & 3 & 6 & 9 & 12 & 15 & 0 & 3 & 6 & 9 & 12 & 15 \\
\hline Control (water only) & 60.7 & 57.0 & 55.2 & 53.0 & 52.7 & 50.4 & 61.2 & 59.1 & 57.0 & 53.6 & 51.7 & 49.5 \\
\hline Hot water at $\left(48^{\circ} \mathrm{C}\right)$ for 2 minutes & 60.7 & 55.2 & 52.3 & 51.4 & 50.1 & 48.1 & 61.2 & 57.9 & 54.8 & 52.3 & 48.2 & 47.4 \\
\hline Hydrogen peroxide (2\%) for 4 minutes & 60.7 & 56.3 & 53.7 & 51.5 & 50.0 & 49.2 & 61.2 & 58.2 & 56.6 & 52.8 & 51.2 & 50.1 \\
\hline Calcium chloride (2\%) for 4 minutes & 60.7 & 59.0 & 58.1 & 55.2 & 53.9 & 52.0 & 61.2 & 60.3 & 59.1 & 55.2 & 54.7 & 53.2 \\
\hline Lemon grass $6 \mathrm{ml} /$ carton (fumigation) & 60.7 & 57.1 & 55.0 & 51.9 & 51.0 & 50.3 & 61.2 & 58.8 & 56.3 & 55.1 & 54.0 & 53.8 \\
\hline Hot water + lemon grass (fumigation) & 60.7 & 57.0 & 55.3 & 52.6 & 51.8 & 51.3 & 61.2 & 59.0 & 56.9 & 55.0 & 54.5 & 53.6 \\
\hline $\begin{array}{l}\text { Hydrogen peroxide + lemon grass } \\
\text { (fumigation) }\end{array}$ & 60.7 & 58.7 & 57.7 & 54.9 & 53.8 & 52.7 & 61.2 & 60.4 & 56.1 & 55.3 & 55.0 & 54.1 \\
\hline $\begin{array}{l}\text { Calcium chloride }+ \text { lemon grass } \\
\text { (fumigation) }\end{array}$ & 60.7 & 58.8 & 58.0 & 55.1 & 54.0 & 53.2 & 61.2 & 60.5 & 59.3 & 57.2 & 56.1 & 55.5 \\
\hline LSD at $5 \%$ & 0.0 & 1.6 & 1.9 & 1.3 & 0.6 & 1.5 & 0.0 & 2.0 & 2.1 & 1.5 & 0.9 & 1.6 \\
\hline
\end{tabular}

Table 8. Effect of some post-harvest treatments on total sugrars $\%$ of Maamoura guava fruits stored at $8 \pm 1^{\circ} \mathrm{C}$ and 90\% RH during 2006 and 2007 seasons

\begin{tabular}{|c|c|c|c|c|c|c|c|c|c|c|c|c|}
\hline \multirow{3}{*}{ Treatments } & \multicolumn{6}{|c|}{ Season 2006} & \multicolumn{6}{|c|}{ Season 2007} \\
\hline & \multicolumn{12}{|c|}{ Storage periods/day } \\
\hline & 0 & 3 & 6 & 9 & 12 & 15 & 0 & 3 & 6 & 9 & 12 & 15 \\
\hline Control (water only) & 5.69 & 6.11 & 6.80 & 7.60 & 8.10 & 9.13 & 5.91 & 6.58 & 6.91 & 8.20 & 9.15 & 9.85 \\
\hline Hot water at $\left(48^{\circ} \mathrm{C}\right)$ for 2 minutes & 5.69 & 5.72 & 5.85 & 6.35 & 6.94 & 7.40 & 5.91 & 6.00 & 6.10 & 6.50 & 7.10 & 7.60 \\
\hline Hydrogen peroxide (2\%) for 4 minutes & 5.69 & 6.10 & 6.86 & 7.90 & 8.11 & 8.40 & 5.91 & 6.40 & 6.72 & 7.85 & 8.00 & 8.45 \\
\hline Calcium chloride (2\%) for 4 minutes & 5.69 & 5.70 & 5.90 & 6.15 & 6.85 & 7.50 & 5.91 & 6.10 & 6.15 & 6.62 & 7.00 & 7.50 \\
\hline Lemon grass $6 \mathrm{ml} /$ carton (fumigation) & 5.69 & 5.85 & 6.41 & 7.50 & 8.10 & 8.65 & 5.91 & 6.18 & 6.42 & 6.60 & 7.15 & 7.75 \\
\hline Hot water + lemon grass (fumigation) & 5.69 & 6.12 & 6.55 & 7.10 & 8.15 & 8.42 & 5.91 & 6.50 & 6.85 & 7.93 & 8.00 & 8.30 \\
\hline $\begin{array}{l}\text { Hydrogen peroxide }+ \text { lemon grass } \\
\text { (fumigation) }\end{array}$ & 5.69 & 6.10 & 6.70 & 7.45 & 8.20 & 8.57 & 5.91 & 6.25 & 6.40 & 7.10 & 7.45 & 8.85 \\
\hline $\begin{array}{l}\text { Calcium chloride }+ \text { lemon grass } \\
\text { (fumigation) }\end{array}$ & 5.69 & 6.15 & 6.85 & 7.60 & 8.35 & 8.89 & 5.91 & 6.50 & 6.85 & 7.93 & 8.85 & 9.50 \\
\hline LSD at $5 \%$ & 0.0 & 0.15 & 0.22 & 0.18 & 0.30 & 0.91 & 0.0 & 0.18 & 0.31 & 0.25 & 0.41 & 0.73 \\
\hline
\end{tabular}

Determination of antifungal activity of lemon grass oil: Lemon grass oil inhibited fungal growth in vitro at $100 \mathrm{ppm}$ with direct added method to the PDA medium also at $6 \mathrm{ml}$ concentration with method indirectly applied as vapor (by heads space technique) as shown in Table (9).

The effect of the vapor of oil shows that oil vapors has more mycelial growth inhibitory effect. The linear growth was determined by conventional directly method that relatively high as compared with values obtained on vapor exposure in closed chamber.

It is evident that the inhibitory effect of the lemon grass oil on mycelial growth of fungi, varied among the fungal species. Inhibition of the growth of these fungal pathogens may be attributed to the effect of citral which is the major component present in lemon grass oil. Our results coincide with those of Rodov et al. (1995).
From a comparison of values, it was appeared that growth of fungi was inhibited by gaseous contact at lower concentration than by medium contact. A possibility that volatiles evaporated from vessel might be concentrated on agar surface, where fungi were inoculated is considered less probable, since volatiles are less soluble to water. According to the lower vapor than medium, it suggested more efficient inhibition of fungi through respiration route than the direct contact through mycelia.

The results of previously published ratio labeling study revealed that the antifungal mechanism of the oil had synthetic inhibition of DNA, RNA, protein and polysaccharides in Candida albicans as reported by Xia et al. (1995).

The results of the present study revealed that the oil emulsion damaged the cell wall and cell membrane to various degrees resulting in cytoplasm leakage. These results are in accordance with Gegoi et al. 
(1997). It is worth to mention that the method used in the present study is the first record in Egypt.

Effect of different treatments on linear growth of $R$. stolonifer as causal agents of soft rot disease: Results in Table (10) indicate that all treatments reduced the linear growth of $R$. stolonifer. Complete inhibition of linear growth was obtained with lemon grass vapors as compared with untreated control.

In this respect, Conway et al. (1994) reported that calcium enhanced tissue develops resistance to fungal infection by stabilizing or strengthening cell wall by making them more resistant to harmful enzymes produced by fungi. Lurie (1999) reported that hot water treatment increased fruit resistance to chilling injury and when combined with fungicides, hot water greatly enhanced efficacy and makes it possible to reduce their application rates. Use of $\mathrm{H}_{2} \mathrm{O}_{2}$ reduces the linear growth of $R$. stoloniferby dipping treatment, Sapers and Simmons (1998).Essential oil extracted from lemon grass has antifungal activity against several plant pathogens, Raweewon (2008).

Table 9. Antifungal activity of crude lemon grass oil by two methods on linear growth of fungus (Rhizopus stolonifer) causing guava rotting

\begin{tabular}{|c|c|c|c|c|c|}
\hline \multicolumn{3}{|c|}{$\begin{array}{c}\text { Directly added to the PDA } \\
\text { medium }\end{array}$} & \multicolumn{3}{c|}{$\begin{array}{c}\text { Indirectly applied as } \\
\text { vapors (by head space } \\
\text { technique) }\end{array}$} \\
\hline $\begin{array}{c}\text { Conc. } \\
\text { (ppm) }\end{array}$ & $\begin{array}{c}\text { Linear } \\
\text { growth } \\
(\mathrm{mm})\end{array}$ & $\begin{array}{c}\text { Reduction } \\
\%\end{array}$ & $\begin{array}{c}\text { Conc. } \\
\text { (ppm) }\end{array}$ & $\begin{array}{c}\text { Linear } \\
\text { growth } \\
\text { (mm) }\end{array}$ & $\begin{array}{c}\text { Red } \\
\text { uctio } \\
\mathrm{n} \%\end{array}$ \\
\hline 0.0 & 90.0 & 0.0 & 0.0 & 90.0 & 0.0 \\
\hline 20 & 51.0 & 43.3 & 2 & 53.0 & 41.0 \\
\hline 40 & 47.2 & 47.6 & 4 & 31.0 & 65.6 \\
\hline 60 & 39.5 & 56.1 & 6 & 0.0 & $\begin{array}{c}100 . \\
0\end{array}$ \\
\hline 80 & 14.3 & 84.1 & - & - & - \\
\hline 100 & 0.0 & 100.0 & - & - & - \\
\hline $\begin{array}{c}\text { LSD } \\
\text { at 5\% }\end{array}$ & 8.3 & - & & 10.2 & - \\
\hline
\end{tabular}

Table 10. Effect of different treatments on linear growth and reduction $\%$ of $\boldsymbol{R}$. stolonifer

\begin{tabular}{|l|c|c|c|}
\hline \multicolumn{1}{|c|}{ Treatments } & Concentration & $\begin{array}{c}\text { Linear } \\
\text { growth } \\
(\mathrm{mm})\end{array}$ & $\begin{array}{c}\text { Reduction } \\
\%\end{array}$ \\
\hline Control & - & 90.0 & 0.0 \\
\hline $\begin{array}{l}\text { Hot water at } \\
\left(48^{\circ} \mathrm{C}\right)\end{array}$ & - & - & - \\
\hline $\begin{array}{l}\text { Hydrogen } \\
\text { peroxide }\end{array}$ & $2 \%$ & 14.5 & 83.9 \\
\hline Calcium chloride & $2 \%$ & 16.8 & 81.3 \\
\hline $\begin{array}{l}\text { Lemon grass } \\
\text { (fumigation) }\end{array}$ & $6 \mathrm{ml}$ & 0.0 & 100 \\
\hline
\end{tabular}

Inhibition of decay in harvested guava fruits: Lemon grass oil reduced decay development in guava fruits during storage by using 2 and $4 \mathrm{ml} / \mathrm{box}$, while decay was completely inhibited by using 6 $\mathrm{ml} / \mathrm{box}$. However, during an additional 6 days, the untreated fruit developed massive decay, reached up to $(90.4 \%)$ of the fruits. While as treated fruits with the lemon grass oil at concentration $6 \mathrm{ml} /$ carton box developed only (10.4\%) decay Table (11). Use of natural volatiles from lemon grass oil has an advantage of clean lines and safety as compared with food preservatives and medicinal drugs treated in solution, because volatiles could be easily removed on standing. By and Large, our original method which was the first record in Egypt gave accurate results as shown previously in the present work.

Table 11. Effect of fumigation with crude lemon grass oil by head space technique on guava fruits (cv. Maamoura) under storage conditions

\begin{tabular}{|c|c|c|c|c|c|c|}
\hline \multirow{3}{*}{$\begin{array}{l}\text { Conc. } \\
(\mathrm{ml})\end{array}$} & \multicolumn{6}{|c|}{ Infection \% } \\
\hline & \multicolumn{6}{|c|}{ Storage periods (days) } \\
\hline & 3 & 6 & 9 & 12 & 15 & $\begin{array}{c}\text { After } \\
\text { marketable* }\end{array}$ \\
\hline Control & 10.5 & 27.5 & 54.0 & 65.0 & 73.6 & 90.4 \\
\hline 2 & 2.5 & 10.5 & 17.5 & 25.0 & 36.0 & 52.3 \\
\hline 4 & 0.0 & 2.5 & 7.5 & 17.5 & 21.5 & 33.7 \\
\hline 6 & 0.0 & 0. & 0.0 & 0.0 & 0.0 & 10.4 \\
\hline $\begin{array}{c}\text { LSD at } \\
5 \%\end{array}$ & 3.0 & 6.1 & 5.8 & 10.5 & 7.6 & 21.8 \\
\hline
\end{tabular}

* Fruits were kept in carton boxes dimension (52 x $27 \times 13$ $\mathrm{cm})$

Effect of different treatments on post-harvest rots: Data in Table (12) indicate that hot water, $\mathrm{H}_{2} \mathrm{O}_{2}, \mathrm{CaCl}_{2}$ and lemon grass vapor which applied as a single treatment reduced the rot incidence during 15 days.

While, integrated treatments between lemon grass vapor and hot water, $\mathrm{H}_{2} \mathrm{O}_{2}$ and $\mathrm{CaCl}_{2}$ was more effective to reduce the disease incidence.

In this respect, El-Gamal et al. (2007) and Raweewon (2008) reported that post-harvest treatment of hot water, $\mathrm{H}_{2} \mathrm{O}_{2}$ and $\mathrm{CaCl}_{2}$ prolonged the storage periods. 
Table 12. Effect of different treatments on post-harvest rots of guava (cv. Maamoura)

\begin{tabular}{|l|c|c|c|c|}
\hline \multirow{2}{*}{ Treatments } & \multirow{2}{*}{ Conc. } & \multicolumn{3}{|c|}{$\begin{array}{c}\text { \% Rhizopus rot } \\
\text { infection days after } \\
\text { inoculation }\end{array}$} \\
\cline { 3 - 5 } & & 5 & 10 & 15 \\
\hline Control (water only) & 0.0 & 62.5 & 100.0 & 100.0 \\
\hline $\begin{array}{l}\text { Hot water at (48 }{ }^{\circ} \mathrm{C} \text { ) for } 2 \\
\text { minutes }\end{array}$ & $5 \%$ & 21.5 & 31.2 & 40.5 \\
\hline $\begin{array}{l}\text { Hydrogen peroxide (2\%) } \\
\text { for 4 minutes }\end{array}$ & $2 \%$ & 15.2 & 22.5 & 32.0 \\
\hline $\begin{array}{l}\text { Calcium chloride (2\%) for } \\
4 \text { minutes }\end{array}$ & $2 \%$ & 9.5 & 14.2 & 21.4 \\
\hline $\begin{array}{l}\text { Lemon grass 6 ml/ carton } \\
\text { (fumigation) }\end{array}$ & $6 \mathrm{ml}$ & 10.2 & 15.0 & 20.0 \\
\hline $\begin{array}{l}\text { Hot water + lemon grass } \\
\text { (fumigation) }\end{array}$ & $\begin{array}{c}5 \mathrm{I} .+6 \\
\mathrm{ml}\end{array}$ & 4.5 & 7.5 & 10.0 \\
\hline $\begin{array}{l}\text { Hydrogen peroxide } \\
\text { lemon grass (fumigation) }\end{array}$ & $\begin{array}{c}2 \%+6 \\
\mathrm{ml}\end{array}$ & 2.5 & 5.0 & 6.3 \\
\hline $\begin{array}{l}\text { Calcium chloride + lemon } \\
\text { grass (fumigation) }\end{array}$ & $\begin{array}{c}2 \%+6 \\
\mathrm{ml}\end{array}$ & 0.0 & 0.0 & 0.0 \\
\hline LSD at 5\% & - & 21.2 & 19.5 & 12.3 \\
\hline
\end{tabular}

Note: (postharvest) (post-harvest)

\section{REFERENCES}

Adisa, V.A. (1985). Fruit rot disease guava (Psidium guajava) in Nigeria. Indian Phytopath., 38(3): 427-430.

Ahmed Amen, K.I. (1987). Studies of fruit quality and storage ability of two apple cultivars as affected by rootstocks, planting systems and density, irrigation, spraying with growth retardants and post-harvest treating with calcium chloride. Ph.D. Thesis Research Int. of Pomology and Floriculture, Poland, Besarica, R.Y. and I. Rekpovski.

Ahmed, E.A. (1995). Effect of Gibberellin, cycocel, calcium and boron, fruit size and position within tree canopy on quality and mineral content of Anna apple fruits during storage. Ph.D. Thesis, Fac. of Agri., Univ. of Alex., Egypt.

Aly, E.Z. and H.A. Ismail (2000). Effect of pre-harvest $\mathrm{GA}_{3}$, $\mathrm{CaCl}_{2}$ and boron treatments on quality and enzymatic browning in balady guava fruits. Annals of Agri. Sci., Moshtohor, Vol. 28(2): 1101-1108, Egypt.

A.O.A.C. (1990). Official Methods of analysis $15^{\text {th }}$ Edition. Association of Official Anal Chem. Vol. (2) p 918 (942015), Washington, D.C., USA.

Chastanger, V.B. and J.M. Ogawa (1979). A fungicide-wax treatment to suppress Botrytis cinerea and protect fresh market tomatoes. Phytopath, 26: 433-469.

Cheaour, F.C.; J. Willemote; Y. Aruk; Y. Desjardin; P.M. Makhlouf and A. Gosselin (1990). A foliar application of calcium chloride delays postharvest ripening of strawberry. J. Am. Soc. Hort. Sci., 115: 789-792.
Cheaour, F.C.; J. Willemote; Y. Aruk; Y. Desjardin; P.M. Makhlouf and A. Gosselin (1991). Postharvest response of two strawberry cultivars to foliar application of $\mathrm{CaCl}_{2}$. Hort. Sci, 26: 1186-1188.

Conway, S.W.; C.E. Sams; C.Y. Wang and J.A. Abbott (1994). Additive effects of postharvest calcium and heat treatments on reducing decay and maintaining quality in apples. J. Am. Soc. Hort. Sci., 119: 49-53.

Crisosto, C.H. and T. Michailides (1991). A possible new role of calcium in postharvest technology. Perishables. Handling. Issue, 72: 10.

El-Gamal, Nadia, G.; F. Abd El-Kareem; Y.O. Fotouh and S. El-Mougy-Nehal (2007). Induction of systemic resistance in potato plants against late and early blight diseases using chemical inducers under greenhouse and field conditions. Research conditions. Res. J. of Agr. and Biol. Sci, 3(2): 73-81.

Gegoi, P.; P. Baruah and S.C. Nakth (1997). Antifungal activity of the essential oil of Litsea cubeba pers. J. Essential Oil Res., 9. 213-215.

Juven, B.J. and M.D. Pierson (1996). Antibacterial effects of hydrogen peroxide and methods for its detection and quantitation. J. Food Prot., 59(11): 1233-1241.

Kartar, S. and K.S. Chauhan (1983). Effect of pre harvest application of calcium, potassium and alar on fruit quality and storage life of guava fruits. Hort. Abst. Vol. 53(7): 5548.

Lucass, E.H. (1944). Determining ascorbic acid in large numbers of plant samples. Ind. Eng. Chem. Anal., Ed. 16: 649-652.

Lurie, S. (1999). Postharvest heat treatments. Postharvest Biol. Technol., 14: 257-269.

Madhukar, J. and S.M. Reddy (1990). Control of fruit-rot of guava by hot water treatment. Indian-Phytopathol, 43: 2, 234-236.

Nawar, A. and T. Ezz (1994). The control of enzymatic browning in Balady guava fruits. Alexandria J. of Agr. Res., 39: 1, 315-329.

Nickhah, S.; H.P. Azerang and A. Maskoki (1999). Investigation into the role of calcium chloride on quality characteristics of pear varieties in cold storage. Agr. Sci. and Technol, 13: 2, 149-158.

Pathmanaban, G.; M. Nagarajan; K. Manian and K. Annamalainathan (1995). Effect of used calcium salts on post harvest preservation in fruits. Madras Agr. J., 82: 1, 47-50.

Raweewon, D. (2008). Natural essential oils from lemon grass (Cymbopogon citrates) to control postharvest anthracnose of mango fruit. International $\mathrm{J}$. of Biotechnol. , 10: 104-108. 
Reberto, I.; O.V. Azquez and T. Maria (1990). Changes in Guava of three maturity stages in response to temperature and relative humidity. Hort. Sci, 25(1): 8687.

Rodov, V.; S. Ben-Yehoshua; R. Albagli and D.Q. Fang (1995). Reducing chilling injury and decay of stored citrus fruit by hot water dips. Postharvest Biol. Technol., 5: 119-127.

Sabry, M.F. (1998). Effect of some Biological treatments on fungal infection, quality and storage ability of apple fruits. M.Sc. Thesis, Cairo Univ., Egypt.

Salmah-Yusof; H. Hashim; W. Mohamed; R. Mohamed; S.H. Ahmed and K.K. Chong (1992). Hot water dip versus vapor heat treatment and their effect on guava (Psidium guajava L.) fruits. Acta Hort., No. 292, 217221.

Samson, F.A. (1980). Tropical fruit. Tropical Agriculture Series, pp. 214. Longman ISBN, London, New York (c.f. M.Sc. Zaghloll Ali, 1994, Alex. Univ. Egypt).

Sapers, G.M. and G.F. Simmons (1998). Hydrogen peroxide disinfection of minimally processed fruits and vegetables. Food Technol., 52(2): 48-52.

Shaaban, Fatma, K.M. (2006). Effect of some pre-and postharvest treatments on storability of guava fruits. M.Sc. Thesis, Fac. Agr., Ain Shams Univ., Egypt.
Sheffer, J.J.; A. Koedam and A. Baerheim (1977). Analysis of essential oils by combined liquid-solid and gas-liquid chromatography. Saertrykkav Meddeletser Norsk Famasytisk Selka, 39, 161-188.

Siddiqui, S.; R.K. Sharma and O.P. Gupta (1991). Physiological and quality response of Guava fruits to posture during storage. Hort. Sci. 26(10): 1295-1297.

Singh, B.P.; H.K. Singh and K.S. Chauhan (1981). Effect of post-harvest calcium treatments on the storage like of guava fruits. Indian J. of Agr. Sci., 51(1) 44-47 [Tropical fruits and Plantation Crops, 51(9): 655, No. 7485].

Smith, F.; A. Gilles; J.K. Hamitn and A.P. Gedees (1956). Colourimetric methods of determination of sugar and related substances. Anal. Chem. 28, 350.

Snedecor, C.W. and W.G. Cochran (1982). Statistics Methods. $7^{\text {th }}$ ed. The lowa State Univ. Press. Ames. Iowa, USA.

Xia, Z.G.; J.X. Yang and P.T. Li (1995). Study on antifungal mechanism of Litsea cubeba oil in Candida albicans. Bull. Hunan. Med. Univ., 20, 107-108.

Yavada, U.T. (1996). Guava (Psidium guajava L.). An exotic tree fruit with potential in Southeastern United States. HortSci. 31:789-794. 